\title{
Cytotoxicity evaluation and the mode of cell death of K562 cells induced by organotin (IV) (2-methoxyethyl) methyldithiocarbamate compounds
}

\author{
Nurul Farahana Kamaludin ${ }^{1 *}$, Nazifa Ismail ${ }^{1}$, Normah Awang ${ }^{1}$, Rapidah Mohamad ${ }^{2}$, Norraphat Uttraphan Pim ${ }^{2}$ \\ ${ }^{1}$ Environmental Health and Industrial Safety Programme, Faculty of Health Sciences, Universiti Kebangsaan Malaysia, Jalan Raja Muda Abdul Aziz, Kuala \\ Lumpur, Malaysia. \\ ${ }^{2}$ Biomedical Science Programme, Faculty of Health Sciences, Universiti Kebangsaan Malaysia, Jalan Raja Muda Abdul Aziz, Kuala Lumpur, Malaysia.
}

\section{ARTICLE INFO \\ Received on: 27/08/2018 \\ Accepted on: 22/01/2019 \\ Available online: 05/06/2019}

Key words:

Organotin (IV),

dithiocarbamate, cytotoxicity, apoptosis, K562.

\begin{abstract}
Two new organotin (IV) dithiocarbamate compounds, which are diphenyltin (IV) (2-methoxyethyl) methyldithiocarbamate (compound 1) and triphenyltin (IV) (2-methoxyethyl) methyldithiocarbamate (compound 2), were tested for their toxicity against human erythroleukemia cells (K562). The potential of both compounds to induce cytotoxicity against K562 cells was determined via MTT assay for 24 hours. The mode of K562 cells' death induced by both compounds was determined by Annexin V-FITC/PI staining assay for 24 hours using the $\mathrm{IC}_{50}$ values obtained from the MTT assay for each compound. This study found that compound $\mathbf{1}$ and compound $\mathbf{2}$ were very toxic to K562 cells, producing $\mathrm{IC}_{50}$ values of less than $5.0 \mu \mathrm{g} / \mathrm{cm}^{3}$. Compound 1 showed higher cytotoxicity against $\mathrm{K} 562$ cells with an $\mathrm{IC}_{50}$ value of $4.0 \mu \mathrm{M}\left(2.41 \mu \mathrm{g} / \mathrm{cm}^{3}\right)$ compared to compound 2 which has an $\mathrm{IC}_{50}$ value of $8.0 \mu \mathrm{M}\left(4.52 \mu \mathrm{g} / \mathrm{cm}^{3}\right)$. In addition to that, both compounds were found to induce about $43.0 \%$ of K562 cell death via apoptosis. In conclusion, the compounds showed good potential to be developed into anti-leukemic agents due to their strong cytotoxicity against K562 cells leading to induction of cell death via apoptosis. Further studies on their mechanisms of action are warranted in order to explore their potential to be developed into anti-leukemic agents.
\end{abstract}

\section{INTRODUCTION}

Chronic myeloid leukemia (CML) is a slowlyprogressing disease where there are too many myeloblasts (white blood cells that do not mature) found in the bone marrow and blood (National Cancer Institute, 2015a). About $15 \%$ of patients with CML are adults, with an estimation of 6,660 new cases diagnosed in United States in 2015 (Siegel et al., 2015). According to the National Cancer Institute (2015b), CML can occur at any age even though the median age of patients diagnosed with $\mathrm{CML}$ is 64 years old.

\section{${ }^{*}$ Corresponding Author}

Nurul Farahana Kamaludin, Environmental Health and Industrial Safety Programme, Faculty of Health Sciences, Universiti Kebangsaan Malaysia, Jalan Raja Muda Abdul Aziz, Kuala Lumpur, Malaysia.

E-mail:nurulfarahana@ukm.edu.my
Most individuals who are diagnosed with CML have a genetic abnormality in their blood cells called the Philadelphia chromosome (Ph) (American Cancer Society, 2016). According to Rowley (1973), Philadelphia chromosome is the result of a reciprocal exchange between the long arms of chromosome 9 with chromosome 22. As a result, it causes the formation of gene combination that causes leukemia, which is the $B C R-A B L$ gene. The $B C R-A B L$ gene causes the production of an enzyme called tyrosine kinase that leads to CML. Improved and continuous ABL tyrosine kinase activity in chronic leukemia cells (K562) will inhibit apoptosis (Bedi et al., 1994; McGahon et al., 1994).

Organotin derivatives were identified to possess the potential to combat cancer (Alama et al., 2009). Over the past few years, a number of studies were conducted using organotin compounds with various functional groups, such as carboxylic acids, amino acids, heterocyclic, and sulfur-based ligands (Han and Sheng, 2006). Interestingly, the biological activity of organotin compounds is strongly influenced by their molecular 
structures and most of them are highly toxic even at very low concentrations (Pellerito et al., 2006). Most current studies showed that organotin (IV) compounds can induce cell death at low concentrations, and therefore exhibited better cytotoxic potential than certain clinical drugs (Alama et al., 2009; Du et al., 2011; Ruan et al., 2011; Yamaguchi et al., 2007). A few other previous studies have shown the potential of organotin (IV) to induce cell death via apoptosis. According to Girasolo et al. (2010), most organotin (IV) compounds, with the exception of dimethyltin (IV) compounds, showed significant cytotoxicity toward HT-29 cells and was suggested to cause cell death via apoptosis.

Understanding the apoptotic mechanism for a disease is very important as it gives an idea about the pathogenesis of an illness and also provides clues on how the disease can be treated (Wong, 2011). The mode of cell death can occur either through apoptosis or necrosis, of which can be identified using Annexin V-FITC and propidium iodide staining assay. Apoptosis is described by its morphological features which include cell shrinkage, condensation of chromatin, and nucleus fragmentation (Kerr et al., 1972; 1994; Wyllie et al., 1980). Apoptotic cells involve the translocation of phosphatidylserine (PS) out of the plasma membrane, which subsequently results in the exposure to external cellular activity (Alabsi et al., 2012). It was demonstrated that (Engeland et al., 1998) the ability to stain plasma membranes by Annexin $\mathrm{V}$ binding containing PS with the presence of calcium ions $\left(\mathrm{Ca}^{2+}\right)$ indicates cell death via apoptosis.

In this study, two new organotin (IV) dithiocarbamate compounds, which are diphenyltin (IV) (2-methoxyethyl) methyldithiocarbamate compound (compound 1) (Mohamad et al., 2016) and triphenyltin (IV) (2-methoxyethyl) methyldithiocarbamate compound (compound 2) (Mohamad et al., 2018) were tested for their toxicity against human chronic myeloid leukemia cells (K562). The aim of this study is to determine the cytotoxic effects and the mode of cell death induced by the new organotin (IV) compounds (2-methoxyethyl) methyldithiocarbamate toward K562 cells.

\section{MATERIALS AND METHODS}

\section{Compounds}

Diphenyltin (IV) (compound 1) and triphenyltin (IV) (compound 2) (2-methoxyethyl) methyldithiocarbamate compounds were synthesized at the School of Chemical Sciences and Food Technology, Faculty of Science and Technology, The National University of Malaysia (UKM) Bangi. An in situ method was used to synthesize the compounds, whereby (2-methoxyethyl)-methylamine was reacted with carbon disulfide $\left(\mathrm{CS}_{2}\right)$ and ammonia solution in ethanol for 2 hours at $<4^{\circ} \mathrm{C}$ to form the dithiocarbamate ligand. The respective organotin (IV) chloride salts were then dissolved in cold ethanol and slowly added to the ligand mixture and stirred for another 2 hours to form the organotin (IV) dithiocarbamate compounds. The synthesis was conducted as described by Mohamad et al. (2016).
Both compounds were then characterized through elemental analysis (Carbon, Hydrogen, Nitrogen, and Sulfur), Fourier-transform infrared analysis, and ${ }^{1} \mathrm{H},{ }^{13} \mathrm{C}$, and ${ }^{119} \mathrm{Sn}$ nuclear magnetic resonance analyses in UKM, Bangi. The chemical structures of compounds 1 and 2 are illustrated in Figures 1 and 2, respectively. Table 1 shows the important physical analysis of both compounds.

\section{Stock preparation}

The stock solutions of compound $1(10 \mathrm{mM})$ and compound $2(10 \mathrm{mM})$ were prepared by dissolving 0.006 and 0.005 $\mathrm{g}$ into $1 \mathrm{ml}$ of dimethylsulfoxide (DMSO). The stock solutions were kept at $-20^{\circ} \mathrm{C}$ and were diluted at a certain concentration prior to the treatment of the cells. Menadione (MENA) was chosen as the positive control in this study as it has been found to induce apoptosis in K562 cells through oxidative stress mechanism (Bonilla-Porras et al., 2011). Menadione also acts as a verifier for the $\mathrm{IC}_{50}$ values obtained from the compounds as its cytotoxic concentrations have been previously established on several leukemic cells, including

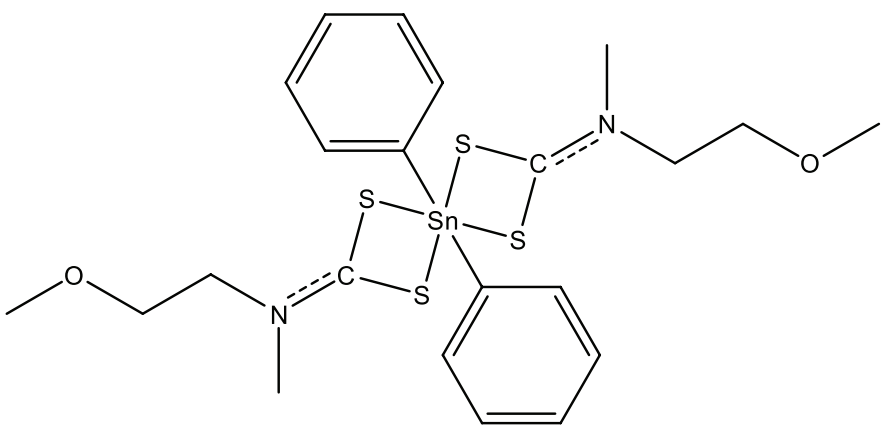

Figure 1. Chemical structure of diphenyltin (IV) (2-methoxyethyl) methyldithiocarbamate compound (compound 1) (Mohamad et al., 2016).

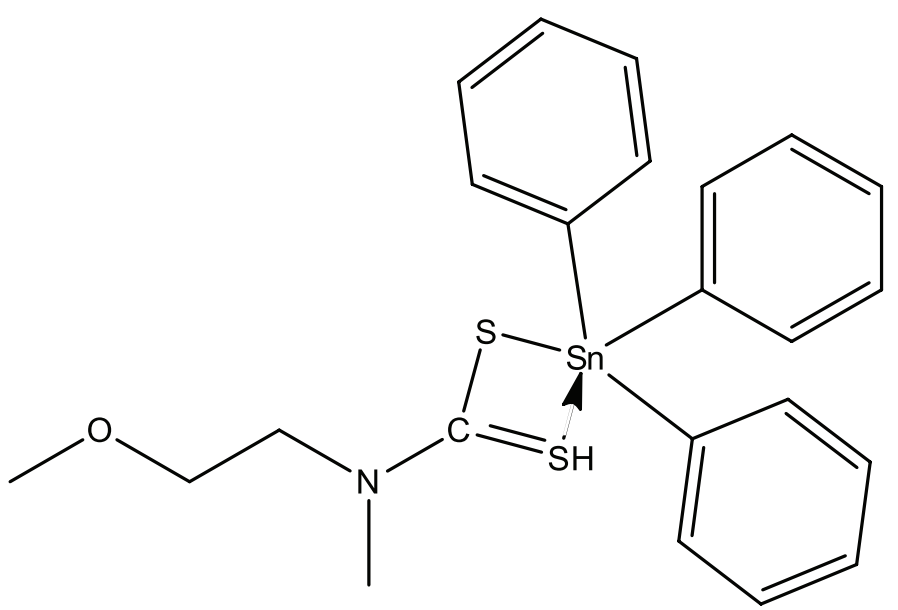

Figure 2. Chemical structure of triphenyltin (IV) (2-methoxyethyl) methyldithiocarbamate compound (compound 2) (Mohamad et al., 2018).

Table 1. Important physical analysis of compound 1 and compound 2.

\begin{tabular}{clcccc}
\hline Compound & Molecular formula & Yield $(\%)$ & Physical form & Molecular weight $(\mathrm{g} / \mathbf{m o l})$ & Melting point $\left({ }^{\circ} \mathbf{C}\right)$ \\
\hline $\mathbf{1}$ & $\left(\mathrm{C}_{6} \mathrm{H}_{5}\right)_{2} \mathrm{Sn}\left[\mathrm{S}_{2} \mathrm{CN}\left(\mathrm{C}_{3} \mathrm{H}_{7} \mathrm{O}\right)\left(\mathrm{CH}_{3}\right)\right]_{2}$ & 78 & White powder & 601.467 \\
$\mathbf{2}$ & $\left(\mathrm{C}_{6} \mathrm{H}_{5}\right)_{3} \mathrm{Sn}\left[\mathrm{S}_{2} \mathrm{CN}\left(\mathrm{C}_{3} \mathrm{H}_{7} \mathrm{O}\right)\left(\mathrm{CH}_{3}\right)\right]$ & 78 & White powder & $565.1-111.1$ \\
\hline
\end{tabular}


K562 (Bonilla-Porras et al., 2011; Nutter et al., 1991; Verrax et al., 2006; Wang et al., 2017; Wu et al., 1993). The stock solution of MENA ( $30 \mathrm{mM}$ ) was prepared by dissolving $0.005 \mathrm{~g}$ of MENA in $1 \mathrm{ml}$ of DMSO. The stock solution was also kept at $-20^{\circ} \mathrm{C}$.

\section{Cell culture}

K562 human chronic myeloid leukemia cell line was purchased from the American Type Culture Collection (ATCC). The cells were maintained in Iscove's Modified Dulbecco's medium (GIBCO, USA) enriched with 10\% fetal bovine serum (Biowest, USA). The cell line was maintained at $37^{\circ} \mathrm{C}$ in $5 \%$ of carbon dioxide $\left(\mathrm{CO}_{2}\right)$ atmosphere according to the recommended protocols by ATCC.

\section{Cell viability assessment}

The K562 cells $\left(5.0 \times 10^{5}\right.$ cells $\left./ \mathrm{ml}\right)$ was seeded and treated with compound $\mathbf{1}$ and compound $\mathbf{2}$ with the highest concentration of $10.0 \mu \mathrm{M}$ in 96-well plates. The desired concentrations gradient was obtained via serial dilution method. The cells were exposed to the compounds for approximately 24 hours. Upon 24 hours of incubation, $20 \mu \mathrm{L}$ of 3-(4,5-dimethylthiazol-2-yl)2,5-diphenyltetrazolium bromide (MTT) salt solution $(5 \mathrm{mg} / \mathrm{ml})$ was added into each of well and was incubated for 4 hours. After 4 hours of incubation, an amount of $180 \mu \mathrm{L}$ supernatant was removed from each well prior the addition of $180 \mu \mathrm{L}$ DMSO. The cells were incubated for another 15 minutes to allow the formazan crystals to be fully dissolved, followed by optical density (OD) measurement using ELISA microplate reader at $570 \mathrm{~nm}$ wavelengths.

\section{Mode of cell death assessment}

The K562 cells were seeded in six-well plate $\left(5.0 \times 10^{5}\right.$ cell $/ \mathrm{ml}$ ) and treated with both compounds at their respective $\mathrm{IC}_{50}$ concentrations. The treated cells were incubated for 24 hours. Upon the completion of 24 hour incubation, $200 \mu \mathrm{L}$ of cells were harvested and transferred into a micro centrifuge tube. The sample was centrifuged at $200 \mathrm{~g}$ for 5 minutes at $4^{\circ} \mathrm{C}$. Then, the supernatant was discarded and $500 \mu \mathrm{L}$ of cold PBS was added into the sample prior to the centrifugation for 5 minutes. The supernatant was then discarded. Next, $150 \mu \mathrm{L}$ of Annexin $\mathrm{V}$ binding buffer and $5.0 \mu \mathrm{L}$ of Annexin V-FITC were added to the sample in a dark condition. The samples were incubated for 15 minutes at the room temperature. Next, an amount of $10 \mu \mathrm{L}$ propidium iodide was added to the samples followed by 2 minutes of incubation at the room temperature. After the incubation period, an amount of $350 \mu \mathrm{L}$ of Annexin $\mathrm{V}$ binding buffer was added to the samples and transferred into falcon tubes. Finally, the samples were analyzed using BDFACS Canto II flow cytometer.

\section{Statistical analysis}

Statistical Analysis Statistical evaluations of the percentage of viable cells along with the concentration of compounds used to treat the cells were calculated using Statistical Package for Social Sciences (SPSS) version 23.0 by employing a one-way analysis of variance. A probability of 0.05 or less was deemed statistically significant $(p<0.05)$.

\section{RESULTS AND DISCUSSION}

This research was conducted to evaluate the cytotoxic effects induced by di- and triphenyltin (IV) (2-methoxyethyl) methyldithiocarbamate compounds against human erythroleukemic cell line (K562 cell) using MTT assay. The graphs in Figures 3 and 4 show that both diphenyltin (IV) (2-methoxyethyl) methyldithiocarbamate compound (compound 1) and triphenyltin (IV) (2-methoxyethyl) methyldithiocarbamate compound (compound 2) were able to reduce $50 \%$ of the K562 cells' viability at the concentrations $4.0\left(2.41 \mu \mathrm{g} / \mathrm{cm}^{3}\right)$ and 8.0 $\mu \mathrm{M}\left(4.52 \mu \mathrm{g} / \mathrm{cm}^{3}\right)$, respectively. Table 2 shows the summary of $\mathrm{IC}_{50}$ values observed from both compounds as well as the positive control, menadione on $\mathrm{K} 562$ cells. The $\mathrm{IC}_{50}$ values (in $\mu \mathrm{M})$ obtained were converted to $\mu \mathrm{g} / \mathrm{cm}^{3}$ using the formula for the purpose of cytotoxic classification (How et al., 2008):

$$
\begin{aligned}
& \text { Mass concentration }\left(\mathrm{mg} / \mathrm{cm}^{3}\right) \\
& =\frac{\text { Molar concentration }(\mu \mathrm{M}) \times \text { Molecular weight }(\mathrm{g} / \mathrm{mol})}{1,000}
\end{aligned}
$$

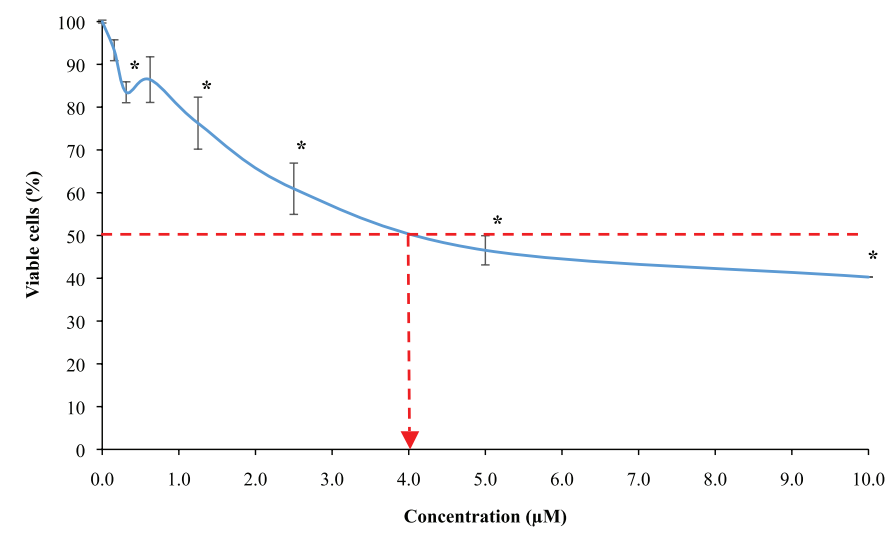

Figure 3. The $\mathrm{IC}_{50}$ value of diphenyltin (IV) compound toward K562 cells after the treatment duration of 24 hours with the highest concentration of $10.0 \mu \mathrm{M}$. The data show the percentage of viable cells $(\%) \pm$ SEM obtained from three consecutive experiments. $*$ Significant difference $(p<0.05)$ from negative control.

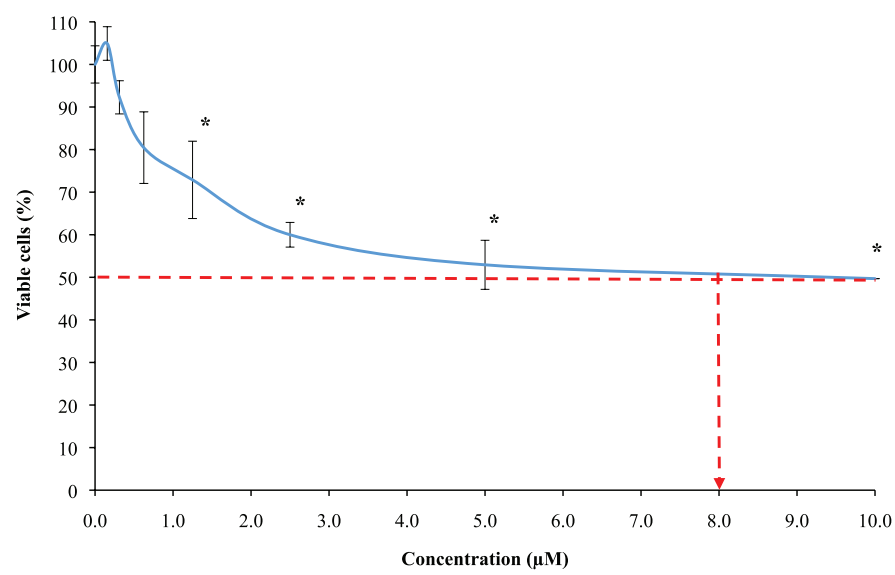

Figure 4. The $\mathrm{IC}_{50}$ value of triphenyltin (IV) compound toward K562 cells after the treatment duration of 24 hours with the highest concentration of 10.0 $\mu \mathrm{M}$. The data show the percentage of viable cells $(\%) \pm$ SEM obtained from three consecutive experiments. *Significant difference $(p<0.05)$ from negative control. 
Table 2. The $\mathrm{IC}_{50}$ values of compound $\mathbf{1}$ and compound $\mathbf{2}$ against $\mathrm{K} 562$ cells.

\begin{tabular}{lc}
\hline Compound & IC $_{50}$ value $(\mu \mathrm{M})$ \\
\hline Compound 1 & 4.0 \\
Compound 2 & 8.0 \\
Menadione (positive control) & 15.2 \\
\hline
\end{tabular}

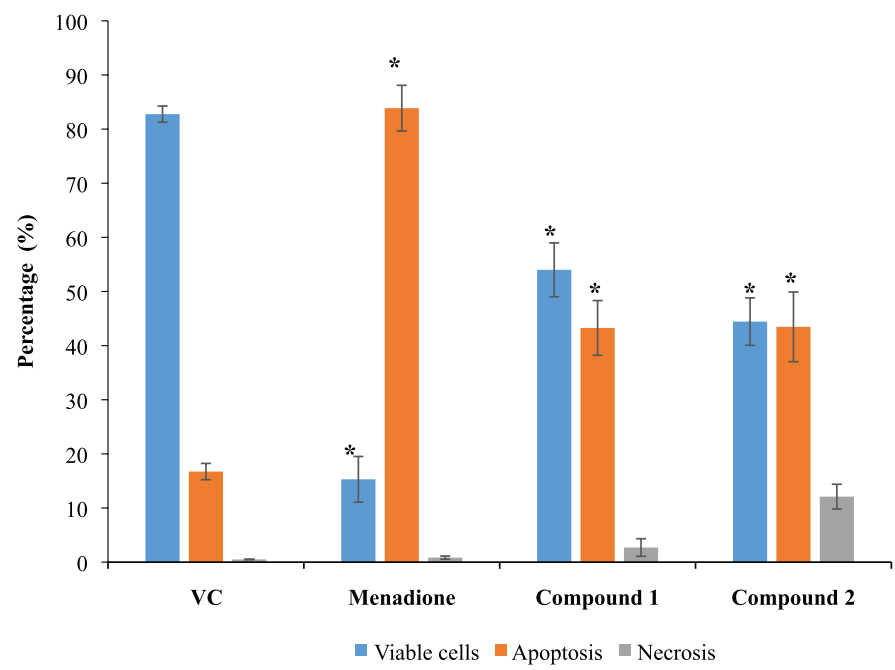

Figure 5. The percentage of viable, apoptotic, and necrotic cells in K562 cells upon treatment with compound $\mathbf{1}$ and $\mathbf{2}$ at $\mathrm{IC}_{50}$ concentrations for 24 hours. The data represent the mean $(\% \pm \mathrm{SEM})$ of three independent experiments. $*$ Significant difference $(p<0.05)$ from negative control.

Dithiocarbamate derivatives are lipophilic compounds with a higher level of solubility in organic solvents than in water, which is one of the important factors for biological activities (Rutkowska et al., 2013). An environment of high lipophilicity helps facilitate the transport of compounds through the membranes in biological systems as well as helping in the complex formation between compounds and the receptor-binding. Therefore, it is suggested that lipophilic properties assist in the process of transporting the compounds across the cell membrane. It was (Huang et al., 2009) who found that the lipophilic nature of this compound has helped in the intracellular interaction, thereby exerting cytotoxicity against the cells.

The MTT assay results showed that compound $\mathbf{1}$ induced stronger cytotoxicity on the K562 cells as compared to compound 2. This was deduced from the $\mathrm{IC}_{50}$ value obtained for compound $\mathbf{1}$ that was $4.0 \mu \mathrm{M}\left(2.41 \mu \mathrm{g} / \mathrm{cm}^{3}\right)$, which was lower than compound 2 that was $8.0 \mu \mathrm{M}\left(4.52 \mu \mathrm{g} / \mathrm{cm}^{3}\right)$. According to a previous study of How et al. (2008), compounds with $\mathrm{IC}_{50}$ values less than 5.0 $\mu \mathrm{g} / \mathrm{cm}^{3}$ are classified as very toxic compounds. Most researchers found that triphenyltin compounds gave stronger cytotoxic effects on the tested cells compared to diphenyltin compounds. This is because triphenyltin consists of three phenyl groups, while diphenyltin consists of only two phenyl groups attached to the tin $(\mathrm{Sn})$ atom. The size and nature of the lipophilic properties of the phenyl, which is a large lipophilic and aromatic group, had been suggested to affect the cytotoxic effects induced by compound 1 and compound 2 against the K562 cells. In addition, organotin (IV) compounds are also characterized as electron acceptors, thus the toxicity of the compounds is proposed to be due to the interactions between the electron donor groups in biomolecules (Awang et al.,
2011). Interestingly in this study, the diphenyltin (IV) compound showed better potency on K562 cells as compared to the triphenyltin (IV) compound. However, statistical analysis showed no significant difference $(p<0.05)$ between both compounds in the study. This study was supported by the research conducted by Gielen and Tiekink (2005) in which the di- and triorganotin (IV) compounds induced strong anti-proliferative effects against many types of cancer cells. This effect is due to the coordination of the ligand by atom or groups to the central metal atom. Thus, it can be suggested that the cytotoxicity of diphenyltin and triphenyltin are quite similar against K562 cells.

Figure 5 shows the percentage of viable, apoptotic and necrotic K562 cells upon treatment with compounds 1, 2 and menadione at their respective $\mathrm{IC}_{50}$ concentrations. In the present study, it was found that the percentage of the externalization of PS in $\mathrm{K} 562$ cells when treated with $\mathrm{IC}_{50}$ concentrations for 24 hours for both di- and triphenyltin compounds were about $43.0 \%$. The results in this assay show similarities with the $\mathrm{IC}_{50}$ values obtained in the MTT assay. Approximately, $50 \%$ of viable K562 cells were detected in the Annexin V-FITC and propidium iodide staining assay compared to the results of MTT assay.

The results from this study also found that the percentage of cells that undergo necrosis for triphenyltin (IV) compound (compound 2) was higher $(12.10 \%)$ as compared to diphenyltin (IV) compound (compound 1) (2.70\%). Apoptotic cell death is a target in developing anticancer treatments. This is because interference of the apoptosis processes promotes tumor initiation and development, and also resistance to treatment (Lowe and Lin, 2000). Kerr et al. (1972) linked apoptosis to the removal of potentially malignant cells, hyperplasia, and tumor development. The reduction of apoptotic activity or its resistance plays an important role in carcinogenesis. The mechanisms that are proposed to be the contributing factors to the inhibition of apoptosis are the disruption of the balance of pro-apoptotic and anti-apoptotic proteins, the inhibition of the caspase function and the impairment of death receptor signals (Wong, 2011).

The important features of necrosis are unlike apoptosis as it produces pro-inflammatory responses (Ricci and Zong, 2011). The inflammatory responses may damage normal tissues, producing mitogenic, or pro-survival cytokine. The molecules can activate the signal pathway that promotes the growth of external cells in the damaged area, and thereby promotes the migration and metastasis of the associated tumor cells (Lotze and Tracey, 2005; Zhou et al., 2004).

Overall, the results of this study showed that compound 1 and compound 2 were able to induce cytotoxic effects on K562 cells in line with the increased treatment concentration used within 24 hours. Both compounds showed strong cytotoxic effects on the $\mathrm{K} 562$ cells with $\mathrm{IC}_{50}$ values less than $5.0 \mu \mathrm{g} / \mathrm{cm}^{3}$. Other than that, the organotin (IV) compounds were also capable of inducing approximately $50 \%$ cell death via apoptosis at their respective $\mathrm{IC}_{50}$ concentrations upon the treatment for 24 hours.

\section{CONCLUSION}

In conclusion, this study has proven that diphenyltin (IV) (2-methoxyethyl) methydithiocarbamate (compound 1) and triphenyltin (IV) (2-methoxyethyl) methyldithocarbamate (compound 2) were able to produce cytotoxic effects on K562 cells in a concentration-dependent manner for a treatment period 
of 24 hours. Interestingly, the assessment on the mode of K562 cells' death showed that both compounds were able to induce cell death via apoptosis upon the treatment with the $\mathrm{IC}_{50}$ concentration for 24 hours. This study indicates that both compounds possess good potential in being developed into new anti-leukemic agents.

\section{ACKNOWLEDGMENTS}

The authors would like to thank the Universiti Kebangsaan Malaysia (GGPM-2016-061) for supporting this study and offer the utmost sincere thanks to the management of the Biocompatibility and Toxicology Lab, Faculty of Health Sciences, Universiti Kebangsaan Malaysia (UKM) Kuala Lumpur for providing the essential laboratory facilities. The authors would also like to channel their gratitude to the laboratory assistants of the Faculty of Health Sciences for their much needed technical support.

\section{FINANCIAL SUPPORT}

None.

\section{CONFLICT OF INTEREST}

\section{Nil.}

\section{REFERENCES}

Alabsi AM, Ali R, Ali AM, Al-Dubai SAR, Harun H, Abu Kasim NH, Alsalahi A. Apoptosis induction, cell cycle arrest and in vitro anticancer activity of gonothalamin in a cancer cell lines. Asian Pasific Journal of Cancer Prevention, 2012; 13:5131-5136.

Alama A, Tasso B, Novelli F, Sparatore F. Organometallic compounds in oncology: Implications of novel organotins as antitumor agents. Drug Discovery Today, 2009; 14:500-508.

American Cancer Society. 2016. How is chemotherapy used to treat cancer? Available at http://www.cancer.org/treatment/ treatmentsandsideeffects/treatmenttypes/chemotherpy/how-ischemotherapy-used-to-treat-cancer [Accessed 24 December 2016].

Awang N, Kamaludin NF, Ghazali RA. Cytotoxic effect of organotin(IV) benzylisopropyldithiocarbamate compounds on chang liver cell and hepatocarcinoma HepG2 cell. Pakistan Journal of Biological Sciences, 2011; 14:768-774.

Bedi A, Zehnbauer A, Barber J, Sharkis S, Jones RJ. Inhibition of apoptosis by Bcr-Abl in chronic myeloid leukaemia. Blood, 1994; 83:2038-2044.

Bonilla-Porras AR, Jimenez-Del-Rio M, Velez-Pardo C. Vitamin $\mathrm{K} 3$ and vitamin $\mathrm{C}$ alone or in combination induced apoptosis in leukemia cells by a similar oxidative stress signalling mechanism. Cancer Cell International, 2011; 11-19.

Du D, Jiang Z, Liu C, Sakho AM, Zhu D, Xu L. Macrocyclic organotin(IV) carboxylates based on benzenedicarboxylic acid derivatives: Syntheses, crystal structures and antitumor activities. Journal of Organometallic Chemistry, 2011; 13:2549-2558.

Engeland MV, Nieland LJW, Ramaekers FCS, Schuttle B, Reutelingsperger CPM. Annexin V-affinity assay: A review on an apoptosis detection system based on phosphatidylserine exposure. Cytometry, 1998; $31: 1-9$.

Gielen M, Tiekink ERT. 2005. Metallotherapeutic Drugs and Metal-Based Diagnostic Agents: The use of metals in medicine. Tin compounds and their therapeutic potential. John Wiley and Sons Limited $422-435$.

Girasolo MA, Rubino S, Portanova P, Calvaruso G, Ruisi G. New organotin(IV) complexes with L-Arginine, Na-t-Boc-L-Arginine and L-Alanyl L-Arginine: Synthesis, structural investigations and cytotoxic activity. Journal of Organometallic Chemistry, 2010; 695:609-618.

Han DY, Sheng CX. Synthesis and characterization of organotin complexes with dithiocarbamates and crystal structures of $\left(4-\mathrm{NCC}_{6} \mathrm{H}_{4} \mathrm{CH}_{2}\right)_{2} \mathrm{Sn}\left(\mathrm{S}_{2} \mathrm{CNEt}_{2}\right)_{2}$ and $\left(2-\mathrm{ClC}_{6} \mathrm{H}_{4} \mathrm{CH}_{2}\right)_{2} \quad \mathrm{Sn}(\mathrm{Cl}) \mathrm{S}_{2} \mathrm{CNBz}_{2}$. Applied Organometallic Chemistry, 2006; 20:283-289.
How FNF, Crouse KA, Tahir MIM, Tarafder MTH, Cowley AR. Synthesis, characterization and biological studies of S-benzyl- $\beta-N$ (benzoyl) dithiocarbazate and its metal complexes. Polyhedron, 2008, 27:3325-2229.

Huang W, Ding Y, Miao Y, Liu MZ, Li Y, Yang GF. Synthesis and antitumor activity of novel dithiocarbamate substituted chromones. European Journal of Medicinal Chemistry, 2009; 44:3687-3696.

Kerr JF, Winterford CM, Harmon BV. Apoptosis - its significance in cancer and cancer theraphy. Cancer, 1994; 73:2013-2026.

Kerr JF, Wyllie AH, Currie AR. Apoptosis: a basic biological phenomenon with wide-ranging implications in tissue kinetics. Br J Cancer, $1972 ; 26: 239-57$.

Lotze MT, Tracey KJ. High-mobility group box 1 protein (HMGB1): Nuclear weapon in the immune arsenal. Nat Rev Immunol, $2005 ; 5: 331-42$.

Lowe SW, Lin AW. Apoptosis in cancer. Carcinogenesis, 2000; 21:485-95.

McGahon A, Bissonette RP, Schmitt M, Cotter K, Green DR, Cotter TG. Bcr-Abl maintains resistance of chronic myelogenous leukaemia cells to apoptotic cell death. Blood, 1994; 83:1179-87.

Mohamad R, Awang N, Kamaludin NF. Synthesis and characterisation of new organotin (IV) (2-Methoxyethyl)methyldithiocarbamate complexes. Res J Pharm Biol Chem Sci, $2016 ; 7: 1920-5$.

Mohamad R, Awang N, Kamaludin NF, Jotani MM, Tiekink ERT. Crystal structures and Hirshfeld surface analyses of bis [N,N-bis(2-methoxyethyl)dithiocarbamato-k2 S, S']di-n-butyltin(IV) and [N-(2-methoxyethyl)-N-methyldithiocarbamato- $\left.\mathrm{\kappa} 2 \quad \mathrm{~S}, \mathrm{~S}^{\prime}\right]$ triphenyltin(IV). Acta Crystallograph Sect E Crystallograph Commun, 2018; $74: 302-8$.

National Cancer Institute. Chronic myelogenous leukaemia treatment. 2015a. Available via https://www.cancer.gov/types/leukaemia/ hp/cml-treatment-pdq (Accessed 11 September 2016).

National Cancer Institute. SEER cancer statistics review 19752011. 2015b. Available via http://seer.cancer.gov/csr/1975_2011/ (Accessed 19 December 2016).

Nutter LM, Cheng AL, Hung HL, Hsieh RK, Ngo EO, Liu TW. Menadione: spectrum of anti-cancer activity and effects on nucleotide in human neoplastic cell lines. Biochem Pharmacol, 1991; 41:1283-92.

Pellerito C, Nagy L, Pellerito L, Szorcsik A. Biological activity studies on organotin (IV) ${ }^{\mathrm{n}+}$ complexes and parent compounds. J Organometal Chem, 2006; 691:1733-47.

Ricci MS, Zong WX. Chemotherapeutic approaches for targeting cell death pathways. Oncologist, 2011; 11:342-57.

Rowley JD. Identificaton of a translocation with quinacrine fluorescence in a patient with acute leukaemia. Ann Génét, 1973; 16:109-12.

Ruan B, Tian Y, Zhou H, Wu J, Hu R. Synthesis, characterization and in vitro antitumor activity of three organotin(IV) complexes with carbazole ligand. Inorgan Chimica Acta, 2011; 365:302-8.

Rutkowska E, Pajak K, Jozwiak K. Lipophilicity: methods of determination and its role in medicinal chemistry. Acta Poloniae Pharm Drug Res, 2013; 70:3-18.

Siegel RL, Miller KD, Jemal A. Cancer statistics 2015. Cancer J Clin, 2015; 65:5-29.

Verrax J, Stockis J, Tison A, Taper HS, Calderon PB. Oxidative stress by ascorbate/menadione association kills K562 human chronic myelogenous leukaemia cells and inhibits its tumour growth in nude mice. Biochem Pharmacol, 2006; 72:671-80.

Wang C, Liu Z, Sun Y, Chen T, Huo X, Meng Q, Liu Q, Sun H, Sun P, Peng J, Maa X, Liu K. A stronger reversal effect of the combination of dasatinib and menadione on P-gp-mediated multidrug resistance in human leukemia K562/Adr cell line. RSC Adv, 2017; 7:17227-35.

Wong RSY. Apoptosis in cancer: from pathogenesis to treatment. J Exp Clin Cancer Res, 2011; 30:1-14.

Wu FYH, Liao WC, Chang HM. Comparison of antitumor activity of vitamins K1, K2 and K3 on human tumor cells by two (MTT and SRB) cell viability assays. Life Sci, 1993; 52:1797-804. 
Wyllie AH, Kerr JF, Currie AR. Cell death: the significance of apoptosis. Int Rev Cytol, 1980; 68:251-306.

Yamaguchi A, Tomiyama K, Sayama Y, Kuriyama T, Nakashima H, Matsuda Y, Arakawa Y. Mechanism on the cell death of T-lymphocytes induced by organotin in vitro. Trace Nutr Res, 2007; 24:90-7.

Zhou Z, Yamamoto Y, Sugai F. Hepatoma-derived growth factor is a neurotrophic factor harbored in the nucleus. J Biol Chem, 2004; 279:27320-6.
How to cite this article:

Kamaludin NF, Ismail N, Awang N, Mohamad R, Pim NU. Cytotoxicity evaluation and the mode of cell death of K562 cells induced by organotin (IV) (2-methoxyethyl) methyldithiocarbamate compounds. J Appl Pharm Sci, 2019; 9(06):010-015. 